\title{
ANALISIS BORAKS PADA ABU KOPRA DI MINAHASA UTARA DAN MINAHASA TENGGARA
}

\author{
Marcela P.M Watania ${ }^{1)}$, Fatimawali', Henki Rotinsulu ${ }^{1)}$ \\ ${ }^{1)}$ Program Studi Farmasi FMIPA UNSRAT Manado 95115
}

\begin{abstract}
Copra ashes are ash produced from burning coconut husk in the copra roasting process after more than three roasts. Noodle producers in Manado and Tombatu were using copra ashes as an additive to noodles because it has benefits as a substitute for borax, which is prohibited from using on food, since it can improve the texture of noodles, as preservatives, improve the color and appearance of noodles. The purpose of this study is to analyze qualitatively and quantitatively the presence of borax compounds in copra ashes. Qualitatively analysis was carried out using the flame and color method, and the quantitative test used the $U V$-Vis spectrophotometry method at the wavelength of $545 \mathrm{~nm}$ and $0.125 \%$ curcumin as the color reagent. The study showed positive result on the qualitative test of the color method against turmeric paper whereas turn to brownish red, and negative result on the flame test whereas turn to red greenish fire, on the quantitative test the sample level $A=1.459 \mathrm{ppm}$ and sample $B=2.092$ this indicates that samples $A$ and $B$ were positive contains borax.
\end{abstract}

Keywords: Copra ashes, food additives, borax and spectrophotometry

\begin{abstract}
ABSTRAK
Abu kopra adalah abu yang dihasilkan dari pembakaran sabut kelapa dalam proses pemanggangan kopra setelah lebih dari 3 kali pemanggangan. Abu kopra oleh produsen mie di Airmadidi dan di Tombatu digunakan sebagai bahan tambahan pada mie karena memiliki manfaat sebagai pengganti boraks yang dilarang penggunaannya pada makanan, karena dapat memperbaiki tekstur mie, sebagai pengawet dan memperbaiki warna dan penampilan mie. Tujuan penelitian ini yaitu menganalisis secara kualitatif dan kuantitatif keberadaan senyawa boraks di dalam abu kopra. Analisis kualitatif dilakukan dengan metode nyala dan warna, dan uji kuantitatif digunakan metode spektrofometri UV-Vis pada panjang gelombang 545 $\mathrm{nm}$ dan kurkumin $0,125 \%$ sebagai pereaksi warnanya. Penelitian menunjukkan hasil positif pada uji kualitatif metode warna yaitu kertas tumerik menjadi merah kecoklatan, dan hasil negatif pada uji nyala yaitu api berwarna merah kehijauan, pada uji kuantitatif kadar sampel $A=1,459$ ppm dan sampel $B=2,092$ ini menunjukkan bahwa sampel A dan B positif mengandung boraks.
\end{abstract}

Kata kunci : Abu kopra, bahan tambahan makanan, boraks dan spektrofotometri. 


\section{PENDAHULUAN}

Di era yang lebih modern ini manusia atau masyarakat menginginkan segala sesuatu yang instan dan cepat di dapat. Hal-hal instan yang menjadi kebutuhan bahkan menjadi gaya hidup manusia saat ini adalah pakaian, transportasi dan yang terpenting ialah makanan.

Dalam mengolah makanan dibutuhkan bahan pokok dan bahan tambhan makanan. Menurut Cahyadi (2006), bahan tambahan pangan (BTP) adalah bahan yang mempunyai atau tidak mempunyai nilai gizi, yang dengan sengaja ditambahkan ke dalam makanan untuk pembuatan, pengolahan, dan penyimpanan.

Balai Besar Pengawasan Obat dan Makanan (BPOM) Sulawesi Utara menemukan mie basah mengandung boraks di 6 produsen di kompleks Pasar Karombasan Manado dan juga menemukan adanya penggunaan abu kopra sebagai bahan tambahan olahan mie basah berdasarkan berita yang dilansir oleh surat kabar Tribun Manado dan ditulis oleh Handhika Dawangi pada Minggu, 20 Mei 2018. Selanjutnya dalam peraturan Menteri kesehatan No.722/MenKes/Per/IX/88 boraks dinyatakan sebagai bahan berbahaya dan dilarang untuk digunakan dalam pembuatan makanan (Depkes, 1998).

Abu kopra adalah abu yang dihasilkan dari pembakaran sabut kelapa dalam proses pemanggangan kopra atau dalam bahasa Manado dikenal dengan "fufu kelapa" setelah lebih dari 3 kali pemanggangan. Abu kopra juga dikenal oleh masyarakat dengan nama yang berbeda-beda, ada yang mengenal abu kopra dengan sebutan abu cina, ada juga yang mengenalnya dengan sebutan abu mie. Menurut Vepriati (2007), meskipun bukan pengawet makanan, boraks sering pula digunakan sebagai bahan pengawet makanan. Boraks sering disalahgunakan untuk mengawetkan berbagai makanan seperti bakso, mie basah, pisang molen, siomay, lontong, ketupat dan pangsit. Selain bertujuan untuk mengawetkan, boraks juga dapat membuat tekstur makanan menjadi lebih kenyal dan memperbaiki penampilan makanan.

Adanya temuan masalah diatas menstimulasi peneliti untuk menemukan penyebab masalah dan meneliti kandungan bahan tambahan yang digunakan melalui kegiatan penelitian tentang boraks dan abu kopra yang berjudul "Analisis Boraks pada Abu Kopra di Minahasa Utara dan Minahasa Tenggara”. Minahasa Utara dan Minahasa Tenggara menjadi pilihan peneliti karena beberapa desa di kabupaten ini memproduksi mie basah yang menggunakan abu kopra sebagai bahan tambahannya karena mayoritas masyarakatnya bekerja sebagai petani kelapa dan kopra kelapa, serta abu kopra sudah dikenal oleh masyarakat sejak dahulu.

\section{METODOLOGI PENELITIAN}

Alat

Alat-alat yang digunakanan dalam penelitian ini yaitu cawan petri, cawan porselin, sudip, pipet tetes, mikro pipet, corong kaca, mortar dan penggerus, aluminium foil, kertas saring, Spektrofotometer UV-Visible, timbangan analitik, gelas kimia, labu erlenmeyer, labu ukur, gelas ukur, pipet volume, batang pengaduk, corong, hot plate, tanur, oven dan pisau dapur.

\section{Bahan}

Bahan-bahan yang digunakan dalam penelitian ini yaitu asam sulfat pekat p.a, asam klorida p.a, aquades, alkohol $96 \%$, kunyit, natrium tetraborat, sampel abu kopra, kurkumin p.a, asam asetat pekat p.a, metanol p.a dan $\mathrm{NaOH}$ p.a.

\section{Prosedur Kerja}




\section{Pembuatan Kertas Tumerik}

Diambil beberapa potong kunyit ukuran sedang lalu ditumbuk dan disaring sampai menghasilkan cairan kunyit berwarna kuning. Kemudian dicelupkan kertas saring kedalam cairan kunyit dan dikeringkan.

\section{Pembuatan Larutan Kurkumin 0,125\%}

Ditimbang kurkumin $125 \mathrm{mg}$ lalu dimasukkan ke dalam labu ukur $100 \mathrm{~mL}$, kemudian ditambahkan sedikit asam asetat pekat, dikocok sampai larut dan ditambahkan asam asetat pekat sampai tanda tera.

\section{Pembuatan Larutan Asam Sulfat Pekat-Asam Asetat Pekat (1:1)}

Diukur $100 \mathrm{~mL}$ larutan asam asetat pekat lalu dimasukkan ke dalam Erlenmeyer 250 $\mathrm{mL}$ dan ditambahkan sedikit-sedikit asam sulfat pekat $100 \mathrm{~mL}$ sambil dikocok pelanpelan sampai homogen.

\section{Pembuatan Larutan $\mathrm{NaOH} 10 \%$}

Ditimbang $\mathrm{NaOH} 10$ gram lalu dilarutkan dengan aquades sampai larut, dimasukkan ke dalam labu ukur $100 \mathrm{~mL}$ dan ditambahkan aquades sampai tanda tera.

\section{Uji Warna Menurut Rohman (2007)}

\section{a. Kontrol positif}

Ditimbang 1 gram boraks, dimasukkan dalam cawan porselin lalu ditambahkan $3 \mathrm{~mL}$ asam klorida $10 \%$, dicelupkan kertas tumerik dan diamati perubahan warna yang terjadi.

\section{b. Pengujian Sampel}

Sampel digerus sampai halus, ditimbang 1 gram sampel dan dioven pada suhu $120^{\circ} \mathrm{C}$ selama 3 jam, lalu dimasukkan ke dalam tanur selama 6 jam suhu $600^{\circ} \mathrm{C}$ hingga menjadi abu biru keputihan, lalu didinginkan. Kemudian dimasukkan dalam cawan petri lalu ditambahkan $3 \mathrm{~mL}$ asam klorida $10 \%$ dan dicelupkan kertas kurkumin atau kertas tumerik. Bila didalam sampel terdapat boraks, kertas kurkumin yang berwarna kuning akan berubah menjadi merah kecoklatan.

\section{Uji Warna Menurut Putri (2011) \\ a. Kontrol positif}

Ditimbang boraks $50 \mathrm{mg}$ dimasukkan dalam gelas kimia, ditambahkan $50 \mathrm{~mL}$ aquades panas, diaduk sampai larut, lalu diteteskan pada kertas tumerik atau kertas kurkumin. Diamati perubahan warna yang terjadi pada kertas tumerik, warna yang dihasilkan dipakai sebagai kontrol positif.

\section{b. Pengujian sampel}

Digerus sampel abu kopra sampai halus, ditimbang 1 gram, dimasukkan dalam gelas kimia ditambahkan $50 \mathrm{~mL}$ aquades panas, diaduk sampai larut lalu diteteskan pada kertas tumerik dan diamati perubahan warnanya.

\section{Uji Nyala Api}

Sampel ditimbang sebanyak 1 gram, digerus hingga halus lalu dioven pada suhu $120^{\circ} \mathrm{C}$ selama 3 jam, kemudian sampel dimasukkan ke dalam cawan porselin, dipijarkan pada tanur selama 6 jam pada suhu $600^{\circ}$ sisa pemijaran ditambahkan 1-2 tetes asam sulfat pekat dan 5-6 tetes metanol, kemudian dibakar, bila timbul nyala api hijau maka menandakan adanya boraks.

\section{Pembuatan Larutan Induk/ Baku Boraks \\ Ditimbang natrium tetraborat $50 \mathrm{mg}$, dimasukkan dalam labu takar $100 \mathrm{~mL}(500$ ppm) lalu dilarutkan dengan aquades sampai tanda tera.}

\section{Pembuatan Kurva Kalibrasi Boraks}

Dibuat larutan boraks 6,25 ppm dipipet 1 $\mathrm{mL}$, dimasukkan ke dalam cawan porselin dan ditambahkan $1 \mathrm{~mL}$ larutan $\mathrm{NaOH} 10 \%$, dipanaskan di atas hot plate pada suhu 100$105^{\circ} \mathrm{C}$ sampai kering, kemudian didinginkan pada suhu ruangan. Ditambahkan $3 \mathrm{~mL}$ larutan kurkumin $0,125 \%$, dipanaskan sambil 
diaduk selama 5 menit, didinginkan lagi. Kemudian ditambahkan $3 \mathrm{~mL}$ larutan asam sulfat-asetat (1:1) dipanaskan sambil diaduk sampai tidak ada warna kuning baik pada cawan maupun pada pengaduk, didiamkan 15 menit. Ditambahkan sedikit alkohol, dimasukkan ke dalam labu takar $100 \mathrm{~mL}$, diencerkan dengan alkohol $96 \%$ sampai garis tanda. Disaring dengan kertas saring, hasil saringan diamati serapannya pada panjang gelombang $545 \mathrm{~nm}$. Lakukan hal yang sama pada larutan boraks konsentrasi 12,5 ppm, 31,25 ppm, 37,5 ppm, 43,75 ppm dan lakukan 3 kali pengulangan.

\section{Preparasi Sampel dan Prosedur Pengukuran}

Sampel digerus dan ditimbang 1 gram, dimasukkan ke dalam labu takar $100 \mathrm{~mL}$ lalu dilarutkan dengan aquades, difortex sampai larut dan ditambahkan aquades sampai tanda tera. Dipipet $1 \mathrm{~mL}$ larutan sampel, dimasukkan ke dalam cawan porselin dan ditambahkan $1 \mathrm{~mL}$ larutan $\mathrm{NaoH} 10 \%$, dipanaskan diatas hot plate $100-105^{\circ} \mathrm{C}$ sampai kering, kemudian didinginkan pada suhu ruangan. Ditambahkan $3 \mathrm{~mL}$ larutan kurkumin 0,125\%, dipanaskan sambil diaduk selama 5 menit, didinginkan lagi. Kemudian ditambahkan $3 \mathrm{~mL}$ larutan asam sulfat-asetat
(1:1) dipanaskan sambil diaduk sampai tidak ada warna kuning baik pada cawan maupun pada pengaduk, didiamkan 15 menit. Ditambahkan sedikit alkohol, dimasukkan ke dalam labu takar $100 \mathrm{~mL}$, diencerkan dengan alkohol $96 \%$ sampai garis tanda. Disaring dengan kertas saring, hasil saringan diamati serapannya pada panjang gelombang $545 \mathrm{~nm}$ dan dilakukan 3 kali pengulangan.

\section{Larutan Kontrol Negatif}

Dipipet $1 \mathrm{~mL}$ aquades dimasukkan dalam cawan porselin ditambahkan $1 \mathrm{~mL}$ $\mathrm{NaOH} 10 \%$ lalu dipanaskan sampai kering, didinginkan dan ditambahkan $3 \mathrm{~mL}$ larutan kurkumin, dipanaskan selama 5 menit sambal diaduk, didinginkan kembali dan ditambahkan $3 \mathrm{~mL}$ larutan asam asetat dan asam sulfat (1:1) dipanaskan sampai warna kuning tidak terlihat lagi, dinginkan dan dimasukkan dalam labu takar $100 \mathrm{~mL}$, diencerkan dengan alkohol $96 \%$ dan disaring, lalu filtratnya dibaca pada panjang gelombang $545 \mathrm{~nm}$.

\section{HASIL DAN PEMBAHASAN}

Setelah melakukan penelitian mengenai analisis abu kopra di Minahasa Tenggara dan Minahasa Utara, maka diperoleh hasil sebagai berikut:

Tabel 1. Hasil Analisis Kualitatif Boraks Kontrol Positif

\begin{tabular}{|c|c|c|c|c|c|}
\hline No. & Sampel & Perlakuan & $\begin{array}{l}\text { Pengamatan } \\
\text { Teori }\end{array}$ & Pengujian & $\begin{array}{l}\text { Reaksi dengan } \\
\text { Kertas Tumerik }\end{array}$ \\
\hline 1. & Natrium Tetraborat & Natrium tetraborat+HCl & $\begin{array}{l}\text { Warna Merah } \\
\text { Kecoklatan }\end{array}$ & $\begin{array}{l}\text { Warna Merah } \\
\text { Kecoklatan }\end{array}$ & Positif (+) \\
\hline 2. & Natrium Tetraborat & $\begin{array}{l}\text { Natrium } \\
\text { Tetraborat+aquades }\end{array}$ & $\begin{array}{l}\text { Warna Merah } \\
\text { Kecoklatan }\end{array}$ & $\begin{array}{l}\text { Warna Merah } \\
\text { Kecoklatan }\end{array}$ & Positif (+) \\
\hline
\end{tabular}

Pada penelitian ini dilakukan analisis kualitatif dan analisis kuantitatif. Tujuan dari dilakukannya analisis kualitatif terlebih dahulu adalah untuk mengetahui bahwa sampel yang diteliti positif mengandung boraks atau tidak. Dalam tabel 1 menunjukkan hasil reaksi dari natrium tetraborat yang direaksikan dengan asam klorida dan natrium tetraborat yang direaksikan dengan aquades, dimana 
menunjukkan adanya perubahan warna pada kertas tumerik dari warna kuning berubah menjadi berwarna merah kecoklatan sesuai teori karena adanya pembentukkan senyawa rosacyanin, maka hasil ini sesuai untuk dijadikan kontrol positif atau pembanding.

Tabel 2. Hasil Analisis Kualitatif Uji Warna Boraks pada Sampel

\begin{tabular}{|c|c|c|c|c|c|}
\hline \multirow[t]{2}{*}{ No. } & \multirow[t]{2}{*}{ Sampel } & \multirow[t]{2}{*}{ Perlakuan } & \multicolumn{2}{|c|}{ Pengamatan } & \multirow{2}{*}{$\begin{array}{l}\text { Reaksi } \\
\text { dengan } \\
\text { Kertas } \\
\text { Tumerik }\end{array}$} \\
\hline & & & Teori & Pengujian & \\
\hline 1. & Abu kopra $\mathrm{A}$ & Sampel+HCl 10\% & $\begin{array}{l}\text { Warna merah } \\
\text { kecoklatan }\end{array}$ & $\begin{array}{l}\text { Warna merah } \\
\text { kecoklatan }\end{array}$ & Positif (+) \\
\hline 2. & Abu kopra B & Sampel+HCl $10 \%$ & $\begin{array}{l}\text { Warna merah } \\
\text { kecoklatan }\end{array}$ & $\begin{array}{l}\text { Warna merah } \\
\text { kecoklatan }\end{array}$ & Positif (+) \\
\hline 3. & Abu kopra A & Sampel+aquades & $\begin{array}{l}\text { Warna merah } \\
\text { kecoklatan }\end{array}$ & $\begin{array}{l}\text { Warna merah } \\
\text { kecoklatan }\end{array}$ & Positif (+) \\
\hline 4. & Abu kopra B & Sampel+aquades & $\begin{array}{l}\text { Warna merah } \\
\text { kecoklatan }\end{array}$ & $\begin{array}{l}\text { Warna merah } \\
\text { kecoklatan }\end{array}$ & Positif (+) \\
\hline
\end{tabular}

Keterangan : Abu kopra A = Abu kopra di Minahasa Utara

Abu kopra B = Abu kopra di Minahasa Tenggara

Setelah diketahui bahwa sampel yang diteliti positif mengandung boraks yang ditandai dengan perubahan warna pada kertas tumerik dari warna kuning berubah menjadi berwarna merah kecoklatan ketika sampel yang ditambahkan dengan asam kloria $10 \%$ di teteskan. Penambahan asam klorida 10\% yaitu untuk mengubah boraks pada sampel menjadi asam borat sehingga ketika direaksikan dengan kertas kurkumin dapat menghasilkan warna merah kecoklatan akibat terbentuknya kompleks boro-kurkumin. Sama halnya dengan sampel yang telah diabukan dalam tanur lalu dilarutkan dalam aquades lalu diteteskan dalam kertas tumerik menghasilkan warna yang sama dengan kontrol positif yaitu terbentuknya senyawa rosacyanin yang menandakan bahwa sampel yang diteliti positif mengandung boraks.

Tabel 3. Hasil Analisis Kualitatif Uji Nyala Api pada Sampel

\begin{tabular}{|c|c|c|c|c|c|}
\hline \multirow[t]{2}{*}{ No. } & \multirow[t]{2}{*}{ Sampel } & \multirow[t]{2}{*}{ Perlakuan } & \multicolumn{2}{|c|}{ Pengamatan } & \multirow{2}{*}{$\begin{array}{l}\text { Reaksi } \\
\text { dengan } \\
\text { Kertas } \\
\text { Tumerik }\end{array}$} \\
\hline & & & Teori & Pengujian & \\
\hline 1. & $\begin{array}{l}\text { Natrium } \\
\text { tetraborat }\end{array}$ & $\begin{array}{l}\text { Natrium tetraborat }+\mathrm{H}_{2} \mathrm{SO}_{4} \\
\text { pekat+Metanol }\end{array}$ & $\begin{array}{l}\text { Nyala api } \\
\text { hijau }\end{array}$ & Nyala api hijau & $\begin{array}{c}\text { Positif } \\
(+)\end{array}$ \\
\hline 2. & Sampel A & $\begin{array}{l}\text { Sampel+ } \mathrm{H}_{2} \mathrm{SO}_{4} \\
\text { pekat+Metanol }\end{array}$ & $\begin{array}{l}\text { Nyala api } \\
\text { hijau }\end{array}$ & $\begin{array}{l}\text { Nyala api merah } \\
\text { kehijauan }\end{array}$ & $\begin{array}{l}\text { Positif } \\
(+)\end{array}$ \\
\hline 3. & Sampel B & $\begin{array}{l}\text { Sampel+ }+\mathrm{H}_{2} \mathrm{SO}_{4} \\
\text { pekat+Metanol }\end{array}$ & $\begin{array}{l}\text { Nyala api } \\
\text { hijau }\end{array}$ & $\begin{array}{l}\text { Nyala api merah } \\
\text { kehijauan }\end{array}$ & $\begin{array}{l}\text { Positif } \\
\qquad(+)\end{array}$ \\
\hline
\end{tabular}


Pada pengujian dengan menggunkan metode uji nyala api sampel menghasilkan nyala api berwarna merah kehijauan berbeda dengan kontrol positifnya yang berwarna hijau akibat adanya reaksi antara boron dan metanol, ini menunjukkan bahwa boraks dalam sampel abu kopra ini tidak dapat diidentifikasi dengan uji ini.

Tabel 4. Absorbansi Larutan Standar

\begin{tabular}{lllll}
\hline & \multicolumn{3}{c}{ ABSORBANSI } & RATA- \\
\cline { 2 - 4 } KONSENTRASI & I & II & III & RATA \\
\hline 6.25 PPM & 0.146 & 0.144 & 0.152 & 0.147 \\
12.5 PPM & 0.266 & 0.271 & 0.275 & 0.27 \\
31.25 PPM & 0.407 & 0.412 & 0.4 & 0.406 \\
37.5 PPM & 0.578 & 0.555 & 0.53 & 0.554 \\
43.75 PPM & 0.686 & 0.699 & 0.695 & 0.693 \\
\hline
\end{tabular}

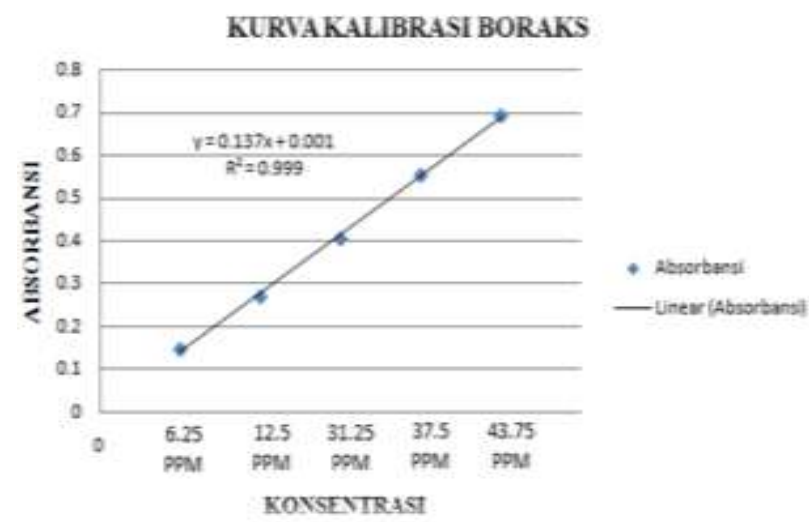

Gambar 1. Kurva Kalibrasi Larutan Standar Boraks

Setelah dipastikan bahwa sampel yang diteliti mengandung boraks lalu dilanjutkan ke bentuk analisis kuantitatif dengan tujuan untuk mencari tahu atau menghitung kadar boraks yang terkandung dalam sampel. Pada analisis kuantitatif digunakan modifikasi metode dari Junianto Choirul (2013) dan (Sudjarwo, 2014), yaitu dengan menggunakan pereaksi kurkumin, hal pertama yang dilakukan adalah membuat kurva kalibrasi dari larutan standar atau baku boraks dengan cara natrium tetraborat dibuat dalam konsentrasi 500 ppm kemudian diencerkan menjadi konsentrasi 6,25 ppm, 12,5 ppm, 31,25 ppm, 37,5 ppm, dan 43,75 ppm lalu direaksikan dengan kurkumin dan ditambahkan dengan asam sulfat dan asam asetat dengan perbandingan (1:1) menghasilkan perubahan warna merah keunguan yang menandakan terbentuknya senyawa rosacyanin, menurut penelitian sebelumnya rosacyanin ini pada penetapan secara spektrofotometri sinar tampak dilakukan dengan melarutkannya dalam alkohol $96 \%$ dan diamati pada panjang gelombang $547 \mathrm{~nm}$. Namun pada penelitian kali ini diamati pada panjang gelombang 545 $\mathrm{nm}$ karena perbedaan sensitivitas alat, setelah diamati absorbansi larutan standar natrium tetraborat dibuatlah kurva kalibrasi dan didapatkan hasil yang linieritasnya memenuhi syarat karena diperoleh nilai $r^{2}=0,999$ dengan persamaan reaksi $y=0,1376 x+0,0012$. Menurut Harmita (2006), sebagai parameter adanya hubungan yang linier digunakan koefisien korelasi $\mathrm{r}^{2}$ pada analisis regreresi linier $\mathrm{y}=\mathrm{ax}+\mathrm{b}$, hubungan linier yang ideal dicapai karena nilai $b=0,0012$ dan nilai $r^{2}=0,999$ mendekati nilai 1 dan membentuk garis lurus yang berarti bahwa konsentrasi berbanding lurus dengan absorbansinya dan menandakan bahwa metode ini dapat digunakan dalam menghitung kadar boraks yang terkandung dalam sampel.

Tabel 5. Absorbansi Sampel A dan B

\begin{tabular}{cccccc}
\hline SAMPEL & $\begin{array}{l}\text { MASSA } \\
\text { (gram) }\end{array}$ & \multicolumn{3}{c}{ ABSORBANSI } & $\begin{array}{c}\text { RATA- } \\
\text { RATA }\end{array}$ \\
\cline { 3 - 5 } & & I & II & III & \\
\hline Sampel A & 1 & 0.326 & 0.328 & 0.328 & 0.327 \\
Sampel B & 1 & 0.414 & 0.413 & 0.415 & 0.414 \\
\hline
\end{tabular}

Untuk menghitung kadar boraks dalam sampel, harus diketahui terlebih dahulu absorbansi sampel, maka dilakukan pembacaan absorbansi sampel abu kopra 
sesuai dengan yang ada dalam tabel 5, dimana demi mendapatkan hasil yang akurat maka dilakukan tiga kali replikasi lalu diambil hasil absorbansi rata-ratanya.

Tabel 6. Absorbansi Kontrol Negatif

Absorbansi dari kontrol negatif digunakan untuk menghitung absorbansi murni dari sampel tanpa dipengaruhi oleh absorbansi dari reagen warnanya yaitu kurkumin.

Tabel 7. Kadar Sampel A dan Sampel B

\begin{tabular}{ll}
\hline SAMPEL & KADAR $(\mathrm{X})$ \\
\hline Sampel A & $1,459 \mathrm{ppm}$ \\
Sampel B & $2,092 \mathrm{ppm}$ \\
\hline
\end{tabular}

Kadar boraks dalam sampel A adalah 1,459 ppm dan kadar boraks dalam sampel B adalah 2,092 ppm. Ini berarti bahwa abu kopra yang ada di daerah Minahasa Utara dan Minahasa Tenggara tidak dapat dijadikan sebagai bahan tambahan makanan karena jika dikonsumsi akan berbahaya bagi kesehatan. Pada penelitian ini juga dibuat kontrol positif dan negatif yang berguna dalam mengidentifikasi dan menghitung kadar boraks dalam sampel. Dari hasil penelitian yang didapat setelah dibandingkan dengan penelitian dari Daniel Yulianto (2013) dan Fadjar Kurnia Hartati (2017) menunjukkan kesesuaian hasil uji kualitatif boraks dengan metode Rohman (2007) dimana terbentuknya kompleks senyawa boro-kurkumin pada kertas tumerik yang dicelupkan ataupun yang diteteskan pada sampel sesuai juga dengan hasil dari kontrol positifnya, dan untuk hasil uji kuantitatif dilakukan perbandingan dengan penelitian sebelumnya dari Sudjarwo (2014) dimana terdapat kesesuaian hasil yaitu terbentuknya kompleks senyawa rosasianin merah (boro-kurkumin) yang stabil dan spesifik. Reaksi ini dapat berlangsung dalam suasan asam oleh karena itu digunakan pereaksi asam asetat pekat-asam sulfat pekat. Walaupun juga terdapat perbedaan didalamnya yaitu pada warna larutan uji, kontrol positif serta larutan sampelnya. Pada penelitian Sudjarwo (2014) warna larutan

\begin{tabular}{ll}
\hline SAMPEL & ABSORBANSI \\
\hline Kontrol Negatif & 0,125
\end{tabular}

kontrol positif (standarnya) berwarna orange kemerahan pudar, larutan sampelnya berwarna kuning kehitaman. Sedangkan pada penelitian kali ini sesuai dengan teori yaitu menghasilkan larutan sampel berwarna merah keunguan pudar sesuai dengan kontrol positifnya atau larutan standarnya dan untuk larutan kontrol negatifnya berwarna orange kecoklatan pudar. Dan ini menunjukkan bahwa penelitian ini sesuai dan sampel yang diteliti positif mengandung senyawa yang berbahaya yaitu natrium tetraborat atau boraks. Dari penelitian ini menunjukkan bahwa abu kopra tidak dapat digunakan sebagai bahan tambahan makanan, untuk itu disarankan untuk menggunakan bahan tambahan makanan yang aman yaitu sebagai pengawet asam benzoat, sodium benzoat, asam propionat. Sebagai pewarna makanan ponceau $4 \mathrm{R}$, merah allura, sunset yellow dan lain-lain penyedap rasa dan aroma MSG (Mono sodium glutamat), pemutih dan pematang tepung yaitu asam askorbat dan lainnya. Bahan-bahan tambahan makanan ini aman digunakan sesuai dosis yang berlaku.

\section{KESIMPULAN}

Berdasarkan hasil penelitian bahwa :

1. Dari 2 sampel yang diteliti secara kualitatif dan kuantitatif, keduanya menunjukan hasil yang sama yaitu sampel A (Minahasa Utara) dan sampel B (Minahasa Tenggara) positif mengandung boraks karena adanya perubahan warna yang positif terjadi pada uji warna 
walaupun pada uji nyala api menunjukkan hasil yang negatif. Ini menyimpulkan bahwa abu kopra tidak aman dijadikan sebagai bahan tambahan makanan karena mengandung senyawa boraks yang berbahaya bagi kesehatan.

\section{DAFTAR PUSTAKA}

Cahyadi, Wisnu. 2006. Analisis dan Aspek Kesehatan Bahan Tambahan Pangan. Bumi Aksara. Jakarta

Dawangi, Handhika. 2018. BBPOM Manado Temukan Mie Basah Mengandung Boraks di 6 Produsen. Tribun Manado. 20 Mei

Departemen Kesehatan dan Direktur jenderal POM. 1998. Peraturan Menteri Kesehatan Republik Indonesia Tentang Bahan Tambahan Makanan. Direktur Jenderal POM. Jakarta

Hartati, K. Fadjar. 2017. Jurnal Teknologi Proses dan Inovasi Industri. Analisis Boraks Secara Cepat, Mudah dan Murah pada Kerupuk. 01 (2). Universitas Dr. Soetomo. Surabaya

Junianto. Choirul. 2013. Jurnal Ilmiah Mahasiswa Universitas Surabaya. Analisis Boraks pada Bakso Daging Sapi A dan B yang Dijual di Daerah Kenjeran Surabaya Menggunakan Spektrofotometri. 02 (2), Fakultas Farmasi Universitas Surabaya. Surabaya

Rohman, A. 2007. Kimia Farmasi Analisis. Pustaka Pelajar: Yogyakarta

Sudjarwo, et al. 2014. Jurnal Berkala Ilmiah Kimia Farmasi. Validasi Metode Spektrofotometri-VIS pada Penetapan Kadar Boraks di Dalam Bakso. 01 (3). Fakultas Farmasi. Universitas Airlangga
2. Kadar boraks yang terkandung dalam kedua sampel yaitu sampel A (Minahasa Utara) dengan massa 1 gram kadarnya 1,459 ppm, dan sampel B (Minahasa Tenggara) dengan massa 1 gram kadarnya adalah 2,092 ppm.

Vepriati, N. 2007. Survailans Bahan Berbahaya pada Makanan di Kabupaten Kulon Progo. Dinas Kesehatan Kulon Progo. Kulon Progo

Yulianto, Daniel. 2013. Jurnal Ilmiah Mahasiswa Universitas Surabaya. Analisis Boraks dalam Sampel Bakso Sapi I, II, III, IV, V, VI, VII, dan VIII yang Beredar di Pasar Sopoyonodan Pasar Jagir. 02 (2). Fakultas Farmasi Universitas Surabaya. Surabaya 